\title{
Advances in systematic knowledge of Australian Loranthaceae and Viscaceae: a review
}

\author{
Bryan A. Barlow
}

\begin{abstract}
Barlow, Bryan A. (Australian National Herbarium, CSIRO Division of Plant Industry, GPO Box 1600, Canberra, ACT 2601. Australia) 1996. Advances in systematic knowledge of Australian Loranthaceae and Viscaceae: a review. Telopea 6(4): 851-862. Better understanding of taxonomy and relationships of Australian Loranthaceae and Viscaceae has contributed significantly to views on endemism and migration in these families and in the Australian flora generally.
\end{abstract}

\section{Introduction}

When they are broadly defined as perennial aerial parasitic angiosperms attached to tree branches, almost all mistletoes in Australia belong to the families Loranthaceae and Viscaceae. Because of the unusual and very interesting biology of these plants, they have become a model group for a broad range of studies, encompassing host-parasite physiology, host-parasite co-adaptation, dispersibility and biogeography.

Over the last 40 years systematic knowledge of Loranthaceae and Viscaceae has advanced greatly, in parallel with advances in knowledge of mistletoe biology. Lawrie Johnson has maintained a long interest in these plants, and through his herbarium work has contributed to the framework of our present systematic knowledge of them.

\section{Taxonomy of Australian Loranthaceae and Viscaceae - overview}

Over the last century the taxonomic history of Loranthaceae and Viscaceae has been exceedingly turbulent. It has led to the accumulation of a very large number of names now placed in synonymy, and to very complex tasks of systematic and taxonomic resolution.

Since Lawrie Johnson first became interested in mistletoes, even their family status has changed. Until about 1970, Loranthaceae and Viscaceae were generally treated as subfamilies of a single family Loranthaceae. Significant differences in embryology (Maheshwari et al. 1957), karyology (Barlow 1963) and morphology (Kuijt 1968) provided strong evidence for their restoration as distinct families, as earlier proposed by Batsch (1802), Miers (1851) and Agardh (1858). Contemporary students of higherlevel angiosperm classification all accepted their status as distinct families (Thorne 1976, Takhtajan 1980, Dahlgren 1980, Cronquist 1981). On morphological grounds there are reasonable arguments that the families are not even directly related (Kuijt 1968, 1969). Kuijt (1968) also segregated a third family Eremolepidaceae (not in Australia) from Viscaceae.

In early taxonomic inventories, most species were referred to two large genera, Loranthus and Viscum. This was the situation when the first floras of Australia (Bentham 1867) and the various States were prepared. However in many papers, mostly published 
between 1894 and 1896, Van Tieghem distinguished numerous segregate genera and new species. Many of Van Tieghem's critical observations on inflorescence and flower structure provided the framework of the current taxonomic treatments of the two families. However Van Tieghem's descriptions were usually cryptic, and his use of diagnostic characters for generic delimitation was often mechanical. Largely through the influence of Engler and Prantl (1894, 1897), Van Tieghem's genera were mostly reduced to sectional rank or lower, and the two large genera Loranthus and Viscum remained in favour.

Credit for resolution of these extreme taxonomic treatments belongs largely with Danser $(1929,1933)$, who critically reviewed Van Tieghem's work, and applied generic concepts which were consistent with those used elsewhere at the time. Although Danser did not accept Loranthaceae and Viscaceae as distinct families, his work has provided the framework for the current generic treatment of these two families. Today Loranthaceae are accepted as comprising about 74 genera and 1300 species, and Viscaceae 7 genera and about 400 species (Kuijt 1989).

The most recent taxonomic research in Loranthaceae and Viscaceae (in papers too numerous to cite) is by J. Kuijt (new world), B.A. Barlow (Asia-Australasia) and R.M. Polhill and D. Wiens (Africa). For the most part, this work has refined the generic and specific framework established by Danser. The most significant developments are the addition of many species discovered as new to science since Danser's time, and the recognition of a number of new genera (which approximately balances the number reduced to synonymy).

The taxonomic history of Loranthaceae and Viscaceae in Australia conforms with the broader development outlined above, and is summarized in Tables 1 and 2 (which exclude taxa of Norfolk and Lord Howe Islands). The first comprehensive treatment of mistletoes for Australia was that of Blakely (1922a, 1922b, 1922c, 1923, 1924, 1925, 1928), and it followed Engler and Prantl's (1897) system which placed most species in two large genera Loranthus and Viscum.

Table 1. Australian genera and species of Loranthaceae (sens. str.), as recognized by successive students of the family. Epithets shown in italics under Danser indicate species accepted by him but not known from Australia at the time.

\begin{tabular}{l|l|l}
$\begin{array}{l}\text { Blakely } \\
\text { (1922-1925) }\end{array}$ & $\begin{array}{l}\text { Danser } \\
\mathbf{( 1 9 2 9 - 1 9 3 8 )}\end{array}$ & $\begin{array}{l}\text { Barlow } \\
\text { (1962-1993) }\end{array}$ \\
\hline $\begin{array}{l}\text { ATKINSONIA } \\
\text { ligustrina }\end{array}$ & $\begin{array}{l}\text { ATKINSONIA } \\
\text { ligustrina }\end{array}$ & $\begin{array}{l}\text { ATKINSONIA } \\
\text { ligustrina }\end{array}$ \\
\hline NUYTSIA & NUYTSIA & NUYTSIA \\
floribunda & floribunda & floribunda \\
\hline PHRYGILANTHUS & PHRYGILANTHUS & MUELLERINA \\
celastroides & celastroides & celastroides \\
eucalyptoides & eucalyptoides & eucalyptoides \\
myrtifolius & myrtifolius & myrtifolia \\
bidwillii & bidwillii & bidwillii \\
\hline & & CECARRIA \\
& obtusifolius & obtusifolia
\end{tabular}




\begin{tabular}{|c|c|c|}
\hline $\begin{array}{l}\text { Blakely } \\
\text { (1922-1925) }\end{array}$ & $\begin{array}{l}\text { Danser } \\
(1929-1938) \\
\end{array}$ & $\begin{array}{l}\text { Barlow } \\
(1962-1993)\end{array}$ \\
\hline \multirow{4}{*}{$\begin{array}{l}\text { LORANTHUS } \\
\text { dictyophlebus } \\
\text { - }\end{array}$} & AMYLOTHECA & AMYLOTHECA \\
\hline & dictyophleba & dictyophleba \\
\hline & - & subumbellata \\
\hline & & DECAISNINA \\
\hline- & hollrungii & hollrungii \\
\hline signatus var. & signata & congesta \\
\hline- & - & angustata \\
\hline biangulatus & biangulata & biangulata \\
\hline brittenii & brittenii & brittenii \\
\hline- & - & triflora \\
\hline \multirow[t]{2}{*}{ signatus } & signata & signata \\
\hline & LYSIANA & LYSIANA \\
\hline exocarpi var. & vittata & spathulata \\
\hline exocarpi & exocarpi & exocarpi \\
\hline exocarpi var. & exocarpi & subfalcata \\
\hline- & - & maritima \\
\hline casuarinae & casuarinae & casuarinae \\
\hline- & - & filifolia \\
\hline linearifolius & linearifolia & linearifolia \\
\hline \multirow[t]{2}{*}{ murrayi } & murrayi & murrayi \\
\hline & DACTYLIOPHORA & DACTYLIOPHORA \\
\hline \multirow[t]{2}{*}{-} & novaeguineae & novaeguineae \\
\hline & DENDROPHTHOE & DENDROPHTHOE \\
\hline odontocalyx v. & falcata & curvata \\
\hline vitellinus var. & falcata & glabrescens \\
\hline vitellinus & falcata & vitellina \\
\hline odontocalyx & falcata & odontocalyx \\
\hline \multirow[t]{2}{*}{ homoplasticus } & homoplastica & homoplastica \\
\hline & AMYEMA & \\
\hline \multirow[t]{2}{*}{ acacioides } & acacioides & acacioides \\
\hline & & BENTHAMINA \\
\hline \multirow[t]{2}{*}{ alyxifolius } & alyxifolia & alyxifolia \\
\hline & & AMYEMA \\
\hline benthamii & benthamii & benthamii \\
\hline ferruginiflorus & ferruginiflora & bifurcata \\
\hline bifurcatus & bifurcata & biniflora \\
\hline cambagei & cambagei & cambagei \\
\hline congener & congener & congener \\
\hline conspicuus & conspicua & conspicua \\
\hline
\end{tabular}




\begin{tabular}{|c|c|c|}
\hline $\begin{array}{l}\text { Blakely } \\
(1922-1925)\end{array}$ & $\begin{array}{l}\text { Danser } \\
(1929-1938)\end{array}$ & $\begin{array}{l}\text { Barlow } \\
(1962-1993)\end{array}$ \\
\hline- & - & dolichopoda \\
\hline- & - & eburna \\
\hline fitzgeraldii & fitzgeraldii & fitzgeraldii \\
\hline- & friesiana & friesiana \\
\hline gaudichaudii & gaudichaudii & gaudichaudii \\
\hline gibberulus & gibberula & gibberula \\
\hline glaber & glabra & glabra \\
\hline - & haematodes & haematodes \\
\hline - & - & herbertiana \\
\hline hillianus & hilliana & hilliana \\
\hline linophyllus & linophylla & linophylla \\
\hline lucasii & lucasii & lucasii \\
\hline mackayensis & mackayensis & mackayensis \\
\hline miraculosus v. & miraculosa & melaleucae \\
\hline - & - & microphylla \\
\hline miquelii & miquelii & miquelii \\
\hline miraculosus & apiculata & miraculosa \\
\hline nestor & nestor & nestor \\
\hline pendulus & pendula & pendula \\
\hline - & plicatula & plicatula \\
\hline preissii & preissii & preissii \\
\hline- & - & pyriformis \\
\hline quandang & quandang & quandang \\
\hline- & - & quaternifolia \\
\hline queenslandicus & queenslandica & queenslandica \\
\hline sanguineus & sanguinea & sanguinea \\
\hline- & seemeniana & seemeniana \\
\hline- & - & subcapitata \\
\hline- & - & thalassia \\
\hline - & - & tridactyla \\
\hline betchei var. & betchei & villiflora \\
\hline \multirow[t]{2}{*}{ whitei } & whitei & whitei \\
\hline & DIPLATIA & \\
\hline \multirow[t]{2}{*}{ maidenii } & maidenii & maidenii \\
\hline & & DIPLATIA \\
\hline - & - & furcata \\
\hline grandibracteus & grandibractea & grandibractea \\
\hline- & - & tomentosa \\
\hline
\end{tabular}


Table 2. Australian genera and species of Viscaceae, as recognized by successive students of the family. Epithets shown in italics under Danser indicate species accepted by him but not known from Australia at the time.

\begin{tabular}{|c|c|c|}
\hline $\begin{array}{l}\text { Blakely } \\
\text { (1928) }\end{array}$ & $\begin{array}{l}\text { Danser } \\
\text { (1937-1941) }\end{array}$ & $\begin{array}{l}\text { Barlow } \\
\text { (1983a, 1984b) }\end{array}$ \\
\hline KORTHALSELLA & KORTHALSELLA & KORTHALSELLA \\
\hline australis & breviarticulata & breviarticulata \\
\hline- & - & grayi \\
\hline brassiana & opuntia & japonica \\
\hline- & - & leucothrix \\
\hline- & papuana & papuana \\
\hline articulata & opuntia & rubra \\
\hline NOTOTHIXOS & NOTOTHIXOS & NOTOTHIXOS \\
\hline cornifolius & cornifolius ${ }^{\star}$ & cornifolius \\
\hline incanus & incanus* & incanus \\
\hline leiophyllus & leiophyllus* & leiophyllus \\
\hline subaureus & subaureus* & subaureus \\
\hline VISCUM & VISCUM & VISCUM \\
\hline angulatum & articulatum & articulatum \\
\hline bancroftii & bancroftii & bancroftii \\
\hline- & ovalifolium & ovalifolium \\
\hline whitei & whitei & whitei \\
\hline
\end{tabular}

Danser $(1929,1933)$ included Australian taxa in his new generic system. He saw few specimens, and depended largely on species descriptions, especially those of Blakely. Because Danser's detailed revisions were largely centred on Malesia, his generic treatment was not generally taken up in Australia, and the laborious tasks of curating collections in Australian herbaria were mostly not undertaken. When I commenced my work on Australian Loranthaceae in 1960, most Australian collections were still arranged according to Blakely's work of 40 years earlier.

The major exception was Lawrie Johnson's effort to reconcile the collections at the National Herbarium of New South Wales with Danser's new system. Johnson referred the Australian specimens to the several segregate genera which Danser accepted for Australia. In detailed annotations on herbarium sheets, he also identified cases where Danser's allocation of species to genera appeared to be unsatisfactory. In general, Johnson's observations have been supported by subsequent studies. In Sydney he, therefore, not only brought taxonomic treatment of Australian mistletoes up to date, but contributed original observations to refine it.

My subsequent work (Barlow 1962, 1966, 1982, 1984a, 1984b, 1992, 1993) has, in essence, extended and fine-tuned Danser's work, principally in two ways. Firstly, the number of species recognized in Australia has been substantially increased. This is mostly an outcome of exploration, which has revealed many species not previously known in Australia. Some of these are new to science, whilst others are Malesian species newly recorded for Australia. 
Secondly, my intensive and extensive study of Loranthaceae and Viscaceae of the southeast Asian region (Barlow 1974, 1993) has led to some refinement of generic limits, especially in Loranthaceae. This has resulted in a modest increase in the number of genera recognized in Australia.

The most significant advances in knowledge have been in the Loranthaceae. When Lawrie Johnson implemented Danser's revisions for Australia, the known Australian Loranthaceae (sens. str.) comprised 49 species in 8 genera. The family in Australia is currently estimated to comprise 74 species in 12 genera (excluding Norfolk Island). Because of the state of knowledge of the family, it now provides a good basis for analyses of flora evolution and historical biogeography, and it has contributed significantly to understanding these processes in Australia. These aspects of mistletoe biology are discussed below.

\section{Loranthaceae - another old southern family}

The Gondwanan affinities of the Australian flora are now widely documented. Many plant families and genera have been shown to have distributions and patterns of differentiation which are consistent with early development in Gondwana, and with subsequent dispersal on the fragments produced by the Gondwanan breakup. Studies by Johnson and Briggs $(1975 ; 1981)$ made an important contribution to understanding the implications of these events for the differentiation of the Australian flora. They showed that major Australian families such as Myrtaceae, Proteaceae and Restionaceae have complementary patterns of relationship across the lands of the southern hemisphere, consistent with the geophysical history of Gondwana.

The Loranthaceae are another group with a classical conformity with this pattern. Through detailed studies of cytogeography and comparative morphology (Barlow and Wiens 1971; Barlow 1981a, 1990), the family has become a model group for illustrating aspects both of the differentiation of Gondwanan floras in the southern lands, and also of the integration of the component elements of the Australian flora through Tertiary time.

A feature of the Loranthaceae in Australia is that they strikingly illustrate the extent of integration of the Gondwanan and Intrusive Elements (Nelson 1981; Barlow 1981b) of the flora. The most obvious Gondwanan genera are the small temperate ones with many plesiomorphic character states (Atkinsonia, $x=12$; Nuytsia, $x=12$; Muellerina; $x=11$ ). They show relationships with other small genera of New Zealand and temperate South America, and apparently are relicts of the ancestral stock which differentiated in Gondwana.

The other loranth genera in Australia which apparently belong to the Gondwanan element are Cecarria, Dactyliophora, Amyema and Diplatia. They all share a genome of $x=9$ with large chromosomes, which is a derived state in the family. They are more tropical in their habitat requirements than the group mentioned above. Indeed, Cecarria, Dactyliophora and probably Amyema are centred in New Guinea. These genera have presumably differentiated on the Australian plate and, following the Miocene contact with the Sunda plate, have made limited intrusions to the northwest and into the Pacific. Amyema reaches mainland Asia and Samoa (see below).

Cecarria, Dactyliophora and Diplatia are all small genera (1-3 species). Amyema is the largest genus in the region, with 92 species, of which 39 occur in Australia, 28 in New Guinea, and 34 elsewhere in Malesia. Dactyliophora and Diplatia are closely related to Amyema, and are undoubtedly part of the same evolutionary radiation and speciation event. In Australia Amyema and Diplatia species show strong integration 
into the vegetation structure, often having high host specificity, and often then displaying visual resemblance to the preferred hosts (Barlow and Wiens 1977). Amyema is found everywhere in Australia where mistletoes occur. This group clearly has had a long history in Australia, consistent with in situ development as part of the Gondwanan floristic element.

The remaining Australian genera of Loranthaceae are Decaisnina, Amylotheca, Lysiana, Dendrophthoe and Benthamina. They contrast strongly with the group described above in morphology, karyology and usually in geography. Decaisnina, Amylotheca and Lysiana have a genome of $x=12$, with large chromosomes, and differ significantly in ovary structure and germination pattern from the Amyema group. Dendrophthoe and Benthamina have $x=9$, with relatively small chromosomes, and differ from the Amyema group in features of inflorescence and floral structure. These five genera belong to two groups with major centres of speciation and diversity in the southeast Asian region, and strong links with African Loranthaceae. In the Malesian region their species richness attenuates towards the east, and in Australia they are mostly represented by a few species in the tropics and along the east coast. In Australia these genera can be clearly identified with the Intrusive Element of the flora, which entered the region following middle/late Tertiary contact between the Australian and Sunda plates. Their preferred hosts are primarily members of the Intrusive Element occurring in rain forests and monsoon woodlands, although eucalypts are occasionally parasitized.

Even within the family Loranthaceae in Australia, then, there is integration between a Gondwanan component of long standing in the region, and an Intrusive component which has arrived more recently from Malesia (Barlow 1990). A possible explanation, which conforms with the phyletic relationships of Asian and African Loranthaceae, is that Loranthaceae endured the passage northwards on the Indian fragment following the breakup of Gondwana. This fragment presumably carried stocks which had already differentiated morphologically and genomically from other Gondwanan Loranthaceae (Barlow 1990).

The most interesting genus in this scenario is Lysiana, endemic to Australia, with eight species together covering most of the mainland. If Lysiana is indeed derived from an Intrusive stock, it is a good illustration of the extent to which this floristic element has adapted to and colonized even temperate habitats in Australia (Barlow $1990,1993)$. Even here, however, the host preferences are a key to the origin, because few of the preferred hosts are old Gondwanan genera. Although Acacia and Casuarina are commonly parasitized, Eucalyptus is not among recorded hosts.

\section{Viscaceae - a Laurasian family?}

In contrast, the Viscaceae do not clearly exhibit Gondwanan links like the Loranthaceae. At least four of the seven genera (Ginalloa, Korthalsella, Notothixos, Viscum) appear to be centred in the southeast Asian/Malesian region (Barlow 1983b). A fifth genus, Arceuthobium, whilst species-rich in North America, is probably Asian in origin (Hawksworth and Wiens 1972). An eastern Asian origin for Viscaceae has therefore been postulated (Barlow 1983b), with Arceuthobium, Dendrophthora and Phoradendron reaching the New World via the Tertiary Beringian land connection. The family may ultimately be of Gondwanan origin (Barlow 1990), but its major diversification was probably a Tertiary palaeotropic Laurasian event.

All four genera of Viscaceae in Malesia are centred there or in southeast Asia, and show some attenuation across Charles's Line to Papuasia, Australia and the Pacific. 
They are probably all components of the one floristic element, a tropical one with a primary centre in southeast Asia, which has diversified in the Malesian region, and which is represented further southeastwards in Australia only as an attenuated intrusive stock.

\section{Endemism, dispersibility, and effectiveness of sea barriers}

Effective seed dispersal in most mistletoes is by fruit-eating birds, and demonstrates close mutualism involving fruit and embryo structure, germination, and bird anatomy and behaviour (Docters van Leeuwen 1954; Reid 1989, 1995; Barlow and Schodde 1993). The ovoid "seed", 5-12 mm long, is covered by a viscous layer rich in carbohydrates. The seed is removed from the fruit and swallowed whole, and passes through the short alimentary canal of the bird rapidly, commonly in 10-20 minutes. Although nutrients have been absorbed from the viscous layer, it is intact when the seed is voided, usually on to a slender tree branch. The viscous layer cements the seed in place, and it germinates spontaneously once removed from the fruit wall.

Because of the nature of the seed dispersal mechanism, dispersibility in mistletoes is normally very low (Barlow and Schodde 1993). The families have strongly continental distributions, with occurrences on remote islands being exceptional (see below). Present distributions have probably been established primarily through migration over continuous land surfaces, and this allows high confidence in the correlation of phylogeny and migration.

Genetic differentiation in mistletoes is therefore likely to be relatively local, and endemism at species level is accordingly relatively high. Earlier students of the families, such as Blakely and Danser, generally assumed that species distributions did not cross significant water barriers, although Danser did accept a number of very widespread Malesian species, some reaching Australia.

Views of successive authors on levels of endemism in Australian mistletoes are summarized in Table 3. Blakely considered all Australian mistletoes except one species of Viscum to be endemic. Danser accepted only three widespread Malesian loranths as present in northern Australia, but in Viscaceae considered half the species to be non-endemic. Barlow has recorded higher numbers of non-endemic species in both families.

Table 3. Levels of endemism in Loranthaceae and Viscaceae, as recognized by successive students of the family.

\begin{tabular}{lcccccc} 
& \multicolumn{2}{c}{ Species } & \multicolumn{2}{c}{$\begin{array}{c}\text { Non-endemic } \\
\text { species }\end{array}$} & \multicolumn{2}{c}{$\begin{array}{c}\text { Percent } \\
\text { endemism }\end{array}$} \\
& Loranth & Visc & Loranth & Visc & Loranth & Visc \\
$\begin{array}{l}\text { Blakely } \\
(1922-1928)\end{array}$ & 45 & 10 & 0 & 1 & 100 & 90 \\
$\begin{array}{l}\text { Danser } \\
(1929-1941)\end{array}$ & 47 & 10 & 3 & 5 & 94 & 50 \\
$\begin{array}{l}\text { Barlow } \\
(1966-1993)\end{array}$ & 74 & 14 & 17 & 7 & 77 & 50
\end{tabular}


The change in perception of endemism among Australian mistletoes is largely an outcome of exploration since 1960, both in the field and in herbaria. Australian species have been discovered in New Guinea, and new records of New Guinean species have been made in Australia, mostly in Cape York Peninsula. Australian species have been revealed in the flora of the Lesser Sunda Islands. Critical studies have shown that the mistletoes of New Caledonia are all conspecific with species of Australia, New Guinea or New Zealand. The result of these discoveries is that mistletoes, especially Loranthaceae, now appear to conform in their species endemism levels with the general patterns of angiosperm families in Australia.

The only slightly doubtful case of endemism involves Muellerina celastroides. There are two old collections from New Zealand, both by collectors who also visited Australia, and Barlow (1966) suggested that confusion of labels may have occurred. However Norton and Reid (1995) have argued that $M$. celastroides was present as a vagrant in New Zealand, from Australia, and that it became extinct in New Zealand some time ago.

These changes in perception of endemism in Australian mistletoes do not necessarily mean that the assumptions on dispersibility are incorrect. Exchanges between Sundaland, New Guinea, Australia and probably New Caledonia, as reflected in. present species distributions, have probably occurred in latest Tertiary or Quaternary times. They have probably coincided with the several sea level minima which occurred during these times. They are supported by the very common occurrence of mistletoe species on more than one of the major islands of the Malesian archipelago. When allowances are made for intermittent water barriers, most of the species concerned have relatively continuous distributions. They have probably been dispersed over continuous land or narrow water barriers by their usual dispersal agents.

A good example of the limits of such dispersibility involves the Australian species Dendrophthoe glabrescens and D. odontocalyx. Both are widespread in open forests of northern Australia, but are now also known from the Lesser Sunda Islands, one species reaching dry habitats in eastern Java. They have probably reached the region, across a narrow water gap, from northwestern Australia, and their distribution in Malesia is limited by habitat requirements.

This example contrasts with the absence of mistletoes (and mistletoe birds) from Tasmania, although the fossil record shows that they were present throughout the Tertiary period (Macphail et al. 1993). Although habitat requirements in Tasmania may be met at the present time, the present water barrier between Tasmania and the Australian mainland is apparently too broad for normal dispersal to occur.

The constraints on mistletoe dispersal imposed by the dispersal agent are best illustrated by the few notable exceptions to the common distribution patterns. A few loranth species have attained wide distributions in the Pacific, reaching oceanic islands. Most striking is Decaisnina forsteriana, which ranges from the Solomon Islands to Tahiti and the Marquesas. Amyema artensis reaches Samoa and the Caroline Islands. Ileostylus micranthus, a relatively unspecialized New Zealand species, apparently reached Norfolk Island about a century ago. It is significant that these dispersal events have all occurred beyond the range of the specialized bird dispersal agents of the genus Dicaeum, which only reach as far eastwards as the Solomon Islands. Strangely, exceptional dispersal events in loranths probably involve disruption of the symbiosis between mistletoe and specialized bird dispersal agent (Barlow and Schodde 1993). When mistletoe fruits become available to more generalist feeders, dispersal may be less efficient but extend over longer distances. 
An exceptional case of a different nature is Korthalsella (Viscaceae), which is widespread in the Pacific and also reaches remote Indian Ocean islands. In this genus the seeds are very small, and are probably dispersed by external attachment to birds rather than by ingestion. This presumably allows the seeds to remain with the bird dispersal agent for a longer time (Barlow 1983a).

Advances in knowledge of Australian mistletoes thus show them to be a very typical component of the Malesian/Australasian flora. Although normally of low dispersibility, they have migrated through the region, in several directions, as geophysical and biotic circumstances have allowed. Their distributions in the region are probably more a function of ecological requirements, and of time, than strictly of geography.

\section{Mistletoes and conservation issues}

Much current research interest in Australian mistletoes is concerned with questions of environmental impact. In New Zealand, mistletoes are under serious threat, largely through predation by the introduced Australian brush-tailed possum (Norton and Reid 1995). In Australia, in contrast, mistletoes are perceived to be increasing in abundance, and in some situations to be a threat to their host populations (Reid 1995).

Mistletoes are recognized as a problem primarily in situations where the forest habitat has been substantially altered. Heavy infestations, and host tree death, are commonly reported along roadsides, in parks and reserves, and in remnant vegetation in rural areas. Scattered or isolated trees are presumably targets for higher levels of visitation by mistletoe birds, and provide good conditions for mistletoe establishment.

There is increasing awareness that a long history of habitat disturbance in Australia has brought major changes in the structure of biotic communities, even in the absence of introductions of exotic species (Flannery 1994). Mistletoes have clearly become part of this process in this century. They have intricate symbiotic relationships with their hosts, their dispersal agents, and with their predators (Barlow and Wiens 1977). Changes in these interactions have altered mistletoe balance in both directions. In Australia, even though they are native plants, mistletoes are emerging as serious environmental weeds.

Some current research, especially by N. Reid and colleagues at the University of New England, is aimed at better understanding these interactions, and at appropriate environmental management. Implications for forestry and reforestation, both in Australia and beyond, are serious, and there is need to increase research capacity in this area.

\section{Conclusion}

Loranthaceae and Viscaceae have become model groups for study of plant evolution and adaptation, biogeography, physiology, genetics and conservation management. Knowledge derived from Australian studies has made a major contribution in all of these fields. Advances in knowledge have been very significant in the last 40 years, and have been driven by progress in understanding the systematics and relationships of the species.

\section{References}

Agardh, J.G. (1858) Theoria Systematis Plantarum. (Gleerup: Lund).

Barlow, B.A. (1962) Studies in Australian Loranthaceae. I. Nomenclature and new additions. Proc. Linn. Soc. New S. Wales 87: 51-61.

Barlow, B.A. (1963) Studies in Australian Loranthaceae. IV. Chromosome numbers and their relationships. Proc. Linn. Soc. New S. Wales 88: 151-160. 
Barlow, B.A. (1966) A revision of the Loranthaceae of Australia and New Zealand. Austral. J. Bot. 14: 421-499.

Barlow, B.A. (1974) A revision of the Loranthaceae of New Guinea and the south-western Pacific. Austral. J. Bot. 22: 531-621.

Barlow, B.A. (1981a) The loranthaceous mistletoes in Australia. Pp. 555-574 in Keast, A. (ed.), Ecological Biogeography of Australia. (W. Junk: The Hague).

Barlow, B.A. (1981b) The Australian flora: its origin and evolution. Pp. $25-75$ in George, A.S. (ed.), Flora of Australia, vol.1. (Australian Government Printing Service: Canberra).

Barlow, B.A. (1982) Supplement to a revision of the Loranthaceae of Australia. Brunonia 5: 203-212.

Barlow, B.A. (1983a) A revision of the Viscaceae of Australia. Brunonia 6: 25-57.

Barlow, B.A. (1983b) Biogeography of Loranthaceae and Viscaceae. Pp. 19-46 in Calder, D.M. and Bernhardt, P. (eds.), Biology of Mistletoes. (Academic Press: Sydney).

Barlow, B.A. (1984a) Loranthaceae. Pp. 68-131 in George, A.S. (ed.), Flora of Australia vol. 22. (Australian Government Printing Service: Canberra).

Barlow, B.A. (1984b) Viscaceae. :Pp. 131-145 in George, A.S. (ed.), Flora of Australia vol. 22. (Australian Government Printing Service: Canberra).

Barlow, B.A. (1990) Biogeographical relationships of Australia and Malesia: Loranthaceae as a model. Pp. 273-292 in Bass, P., Kalkman, C. and Geesink, R. (eds.), The Plant Diversity of Malesia. (Kluwer: Dordrecht).

Barlow, B.A. (1992) Conspectus of the genus Amyema Tieghem (Loranthaceae). Blumea 36: 293-381.

Barlow, B.A. (1993) Conspectus of the genera Amylotheca, Cyne, Decaisnina, Lampas, Lepeostegeres, and Loxanthera (Loranthaceae). Blumea 38: 65-126.

Barlow, B.A. and Schodde, R. (1993) Bird dispersal of loranthaceous mistletoes to remote Pacific islands: symbiosis in default. Beaufortia 43: 124-129.

Barlow, B.A. and Wiens, D. (1971) The cytogeography of the loranthaceous mistletoes. Taxon 20: 291-312.

Barlow, B.A. and Wiens, D. (1977) Host-parasite resemblance in Australian mistletoes: the case for cryptic mimicry. Evolution 31: 69-84.

Batsch, A.J.C.G. (1802) Tabula Affinitatum Regni Vegetabilis, p. 240. Weiman.

Bentham, G. (1867) Loranthaceae. Flora Australiensis 3: 386-397.

Blakely, W.F. (1922a) The Loranthaceae of Australia. Part i. Proc. Linn. Soc. New S. Wales 47: 1-25.

Blakely, W.F. (1922b) The Loranthaceae of Australia. Part ii. Proc. Linn. Soc. New S. Wales 47: 199-222.

Blakely, W.F. (1922c) The Loranthaceae of Australia. Part iii. Proc. Linn. Soc. New S. Wales 47: 391-414.

Blakely, W.F. (1923) The Loranthaceae of Australia. Part iv. Proc. Linn. Soc. New S. Wales 48: 130-152.

Blakely, W.F. (1924) The Loranthaceae of Australia. Part v. Proc. Linn. Soc. New S. Wales 49: 79-96.

Blakely, W.F. (1925) The Loranthaceae of Australia. Part vi. Proc. Linn. Soc. New S. Wales 50: 1-24.

Blakely, W.F. (1928) The Loranthaceae of Australia. Part vii. Proc. Linn. Soc. New S. Wales 53: 31-50.

Cronquist, A.J. (1981) An Integrated System of Classification of Flowering Plants. (Columbia Univ. Press: New York).

Dahlgren, R.M.T. (1980) A revised system of classification of the angiosperms. Bot. J. Linn. Soc. 80: 91-124.

Danser, B.H. (1929) On the taxonomy and nomenclature of the Loranthaceae of Asia and Australia. Bull. Jard. Bot. Buitenzorg III, 10: 291-373.

Danser, B.H. (1933) A new system for the genera of Loranthaceae Loranthoideae, with a nomenclator for the old world species of this subfamily. Verh. Kon. Akad. Wet. Amsterdam Afd. Natuurk. Sect. 2, 29: 1-128.

Danser, B.H. (1937) A revision of the genus Korthalsella. Bull. Jard. Bot. Buitenzorg III, 14: 115-149.

Danser, B.H. (1938) A new Amyema from Australia. Candollea 7: 242-243.

Danser, B.H. (1940) A supplement to the revision of the genus Korthalsella (Lor.). Bull. Jard. Bot. Buitenzorg III, 16: 329-342.

Danser, B.H. (1941) The British-Indian species of Viscum revised. Blumea 4: 261-319.

Docters van Leeuwen, W.M. (1954) On the biology of some Javanese Loranthaceae and the role birds play in their life history. Beaufortia 4: 105-207.

Engler, A. and Prantl, K. (1894) Loranthaceae. Die Natïliche Pflanzenfamilien 3, 1: 156-198.

Engler, A. and Prantl, K. (1897) Loranthaceae. Die Natürliche Pflanzenfamilien, Nachtrage 1: $124-140$.

Flannery, T.F. (1994) The Future Eaters. (Reed: Sydney). 
Hawksworth, F.G. and Wiens, D. (1972) Biology and Classification of Dwarf Mistletoes (Arceuthobium). (United States Department of Agriculture: Washington).

Johnson, L.A.S. and Briggs, B.G. (1975) On the Proteaceae - the evolution and classification of a southern family. Bot. J. Linn. Soc. 70: 83-122.

Johnson, L.A.S. and Briggs, B.G. (1981) Three old southern families - Myrtaceae, Proteaceae and Restionaceae. Pp. 427-469 in Keast, A. (ed.), Ecological Biogeography of Australia. (W. Junk: The Hague).

Kuijt, J. (1968) Mutual affinities of santalalean families. Brittonia 20: 136-147.

Kuijt, J. (1969) The Biology Of Parasitic Flowering Plants. (University of California Press).

Kuijt, J. (1989) Genera of mistletoes. Pp. 1-4. in Polhill, R.M. (ed.), The Golden Bough vol. 11.

Macphail, M.K., Jordan, G.J. and Hill, R.S. (1993) Key periods in the evolution of the flora and vegetation in western Tasmania I. the Early-Middle Pleistocene. Austral. J. Bot. 41: 673-707.

Maheshwari, P., Johri, B.M. and Dixit, S.N. (1957) The floral morphology and embryology of the Loranthoideae (Loranthaceae). J. Madras Univ. 27B: 121-136.

Miers, J. (1851) Observations on the affinities of the Olacaceae. Ann. Mag. Nat. Hist. 8: 161-184.

Nelson, E.C. (1981) Phytogeography of southern Australia. Pp. $735-759$ in Keast, A. (ed.), Ecological Biogeography of Australia. (W. Junk: The Hague).

Norton, D.A. and Reid, N. (1995) Conservation and management of threatened and pest loranthaceous mistletoes in Australasia: lessons for ecosystem management. J. Environ. Management (in press).

Reid, N. (1989) Dispersal of mistletoes by honeyeaters and flowerpeckers: the components of seed dispersal quality. Ecology 70: 137-145.

Reid, N. (1995) Mistletoe - impacts and management. In After Dieback, Redressing Rural Tree Decline in NSW. (Greening Australia: Sydney) (in press).

Thorne, R.F. (1976) A phylogenetic classification of the angiosperms. Aliso 8: 147-209.

Takhtajan, A. (1980) Outline of the classification of flowering plants (Magnoliophyta). Bot. Rev. 46: 225-359. 